\title{
STUDIES OF THE SHRINKAGE AFTER A SUDDEN ADVANGE, BLUE BANDS AND WAVE OGIVES ON GLAGIAR UNIVERSIDAD (CENTRAL GHILEAN ANDES)
}

\author{
By Louis Lliboutry \\ (Laboratoire de Glaciologie, Faculté des Sciences de Grenoble)
}

\begin{abstract}
The recently discovered Glaciar Universidad is the second largest glacier in central Chile. Aerial photographs taken in 1945 show that just before that date it had undergone a "glacier flood" or sudden advance, similar to those suffered by four other great glaciers of central Chile between 1927 and I947. The cause of these floods is sought. Surface features (firn line, absence of penitentes but presence of "pocketpenitents", glacier mills, dirt cones, water-filled holes with submerged ice crystals in them) prove that Glaciar Universidad is the most northerly glacier in the Andes of an Alpine type. The disposition of blue bands, crevasses, closed crevasses and shear planes is reported. Wave ogives are studied and an explanation is given of why dark Forbes' bands form subsequently on these waves. A kind of unstratified esker of a form similar to a deposit observed by Mr. W. H. Ward in Baffin Island, has been studied, as also has the shearing of the frontal cliff along dirt strata; a theory of both phenomena according to which shear transfers material from the bed to the surface is questioned.

RÉsumé. Ce glacier, récemment découvert, est le deuxième du Chili Central par son étendue. Des vues aériennes de 1945 montrent qu'il venait alors de subir une grande crue, analogue à celles qu'ont eu entre 1927 et 1947 quatre autres grands glaciers du Chili Central. On examine la cause de ces crues. Les aspects superficiels (ligne de névé, absence de pénitents mais présence toutefois de pocket-pénitents, moulins, cônes graveleux, trous pleins d'eau avec cristaux submergés) montrent que le Glaciar Universidad est, en allant vers le sud, le premier glacier de type Alpin des Andes. On signale la disposition des bandes bleues, des crevasses, des crevasses refermées et des cisaillements. On étudie les vagues au pied d'une chute (wave ogives) et l'on explique la formation ultérieure de bandes brunes (chevrons) sur ces vagues. On étudie enfin une sorte d'esker non stratifié semblable à un dépôt observé par Ward à l'île de Baffin, et des cisaillements de la falaise frontale le long de lits de terre. La théorie suivant laquelle le matériau du lit remonte à la surface du glacier grâce à des cisaillements est mise en doute.
\end{abstract}

\section{Exploration AND Survey}

The glacier to be described was officially named Glaciar Universidad after my visit for three days at the beginning of March 1956 , when I was accompanied by two students from the University of Chile, Oscar Gonzalez and Erik Klohn. It lies at lat. $30^{\circ} 40^{\prime} \mathrm{S}$., long. $70^{\circ} 2 \mathrm{I}^{\prime} \mathrm{W}$., above the Chilean town of San Fernando, amidst a splendid massif of crystalline rocks (see map, Fig. I). It flows southwards for $11.6 \mathrm{~km}$. from a height of 4600 to one of $2280 \mathrm{~m}$. With a surface area of $29 \mathrm{~km}^{2}$, it is the second largest glacier of the Chilean Andes after the Glaciar de los Cipreses. ${ }^{\mathrm{I}}$

Whereas the Glaciar de los Cipreses, which can be reached on muleback, has been known since the days of Güssfeldt (1883), the first known crossing of the Glaciar Universidad has only recently taken place, during an ascent of Palomo, an extinct volcano of $4850 \mathrm{~m}$., by W. Bachmann, L. Covarrubias and E. Echeverría. These climbers found at the summit evidence of a previous ascent in 1926. Thus our party was at most the third to walk on the glacier, and there are no long records of its fluctuations.

The east margin was flown over during the first aerial survey of Chile, using the Trimetrogon technique, during the winter of 1945 . There are therefore good photographs of this glacier from the east only (Fig. 2, p. 270). The details of the surrounding massif in the AAF chart are still unsatisfactory, the Glaciar de los Cipreses and the Glaciar Universidad being separated by an imaginary valley. I corrected this error by more careful examination of these photographs, together with some others kindly lent me by F. Marmillod. This alpinist, together with Mrs. Marmillod, Mr. and Mrs. O. Pfenniger and L. Pfenniger, made the first ascent of Cerro Portillo (4986 m.) in 1950.*

* This peak, which is the highest in the area, was surveyed and named by Riso Patrón in I9oo. The Chilean map indicates a higher and unnamed peak of $5000 \mathrm{~m}$. which does not exist; the peak climbed by this party and
named Alto de los Arrieros was in fact Cerro Portillo. 
Prior to my visit to Glaciar Universidad, I made two approximate surveys from Volcán Tinguiririca (4I30 m.) and an unnamed peak ("Punta Rosita", 4040 m.) (see the general view in Fig. 3, p. 269). This line of sight was almost perpendicular to that of the Trimetrogon survey. From these observations I was able to calculate many altitudes to within $20 \mathrm{~m}$., the reference points being Volcán Palomo and Cerro Portillo, which were carefully triangulated by Riso Patrón. I include here a general sketch map of the area (Fig. I), and another of the lower part of Glaciar Universidad (Fig. 4).

\section{General Description}

Glaciar Universidad has two branches, juxtaposed and separated by a medial moraine in the ablation zone. The western branch is nourished on gentle slopes between 4300 and $3500 \mathrm{~m}$. under the lee of a north-south sierra, and then flows down an ice fall of $600 \mathrm{~m}$. In this fall large transverse crevasses appear, which cut the glacier into curved horizontal steps, similar to the steps of an amphitheatre. At the foot of the fall, at $2900 \mathrm{~m}$., beautiful wave ogives are formed, which are discussed below. Here the two branches join together. Subsequently the glacier turns through a right angle towards the south-south-west, and flows over a small step in the rock bed. This breaks up the glacier with a series of crevasses which begin at the point of maximum curvature and proceed outward diagonally. The crevasses in each series follow each other down the slope as sketched in Fig. 4. Lower down two slender medial moraines emerge, but do not protect the glacier from ablation. After this bend, the inside branch of the glacier flows normally, but the eastern part of the outside branch diminishes abruptly $2 \mathrm{~km}$. before the snout and disappears beneath angular fragments of granodiorite; at the same time the central stream (the left side of the western branch) increases to about three times its former width and longitudinal crevasses appear (Fig. 5, p. 270). It seems probable that the bend has caused part of the central stream to penetrate under the outside stream, and it therefore reappears there.

The eastern branch is partially nourished by ice from the slopes of Palomo, which enters through a narrow gap. Owing to this fact and to the lower altitude of its firn region, the eastern branch has receded much more than the western branch in the last decade. In 1945 the two arms were of almost equal breadth and reached the snout together; the medial moraine did not have its present bend to the east, and the eastern branch was also crossed from side to side by a chaos of seracs and wave ogives appeared. In 1945 the wave ogives in the middle of the ablation zone were $140 \mathrm{~m}$. apart on the western branch, and I $10 \mathrm{~m}$. apart on the eastern; to-day only the western branch has wave ogives, and they are $5^{\circ}$ to $80 \mathrm{~m}$. apart. We know that generally one wave ogive is formed in an ice fall each year, ${ }^{2,3}$ so that, when the flow is steady, the distance between two waves gives the annual velocity at the place in question. However as the glacier has not been stationary while the ice has moved from the ice fall to this region, we cannot draw this conclusion. In 1956 the velocity in the central area was probably less than $5^{\circ} \mathrm{m}$. per year.

\section{The Collapse of the Piedmont "Bulb"}

The snout of the glacier lies in a flat valley $2 \mathrm{~km}$. wide and nearly horizontal. This valley is a glacial basin filled with glacio-fluvial sediments (sand and rounded blocks of granodiorite). As can be seen in Fig. 2, the glacier extended I km. further in 1945 than it did in 1956 , and it then covered almost all the plain. It enlarged into a "bulb" of the type described by Tarr and Martin in Alaska, 4 and this bulb was very heavily crevassed, evidence of a sudden and recent increase. In 1956 all the crevasses had disappeared except for a system of roughly circular, concentric crevasses produced by the collapse of a subglacial cave at the front, a common feature in such cases.5, 6, 7 A sketch by Bachmann seems to indicate that most of the shrinkage had occurred by 1949 , although a little ice-dammed lake still existed then. 

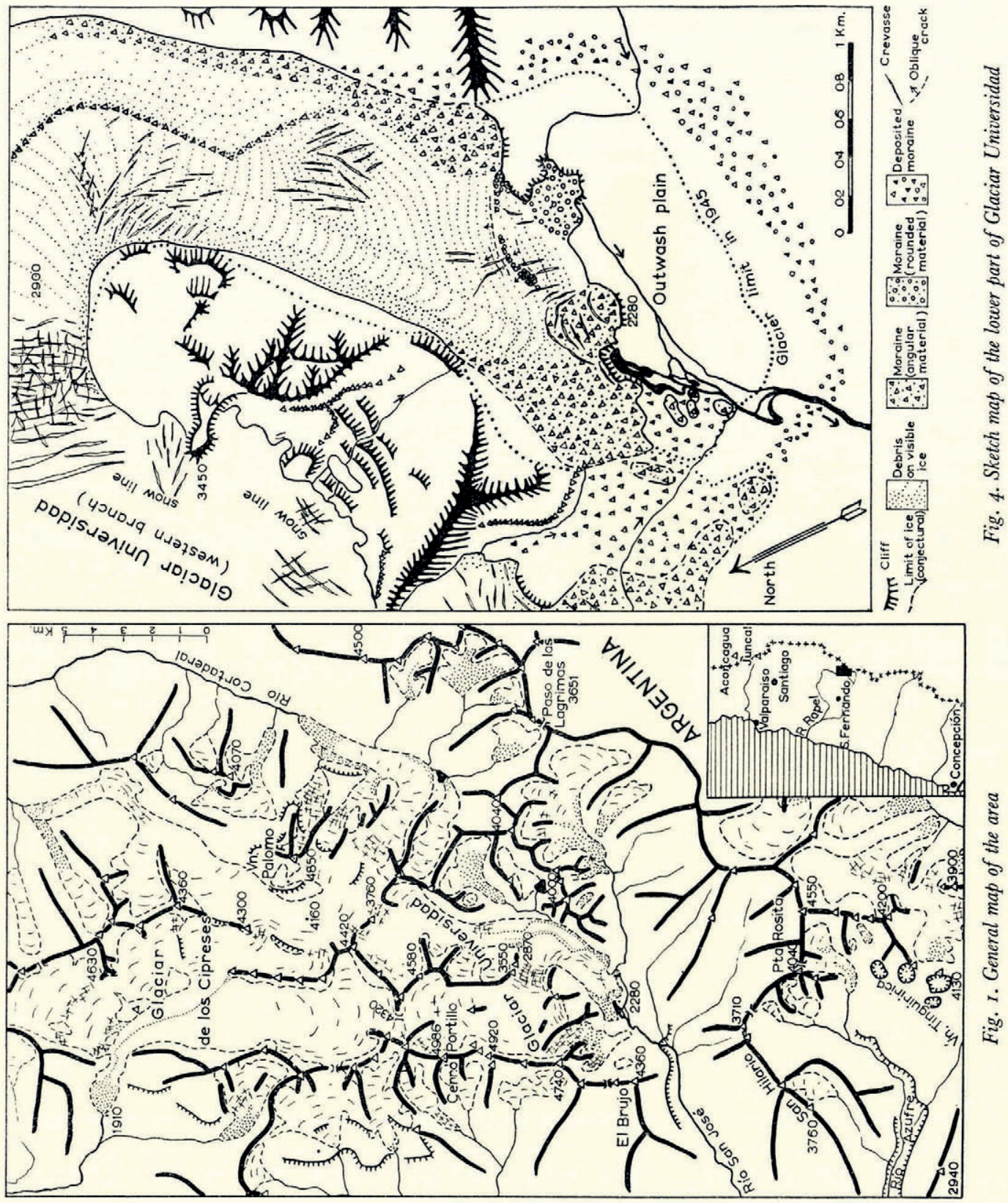
Most of the crevasses must also have disappeared by then, as the surface of the glacier is referred to as being very suitable for walking over.

During the advance, Glaciar Universidad joined a secondary glacier flowing into its right margin, which disappears under thick ablation moraine. Its limits and those of the secondary glacier are therefore difficult to determine; moreover several isolated, debriscovered cones of dead ice remained in this area in 1956 .

On the upper parts of Glaciar Universidad there had been little change. After 1945 the surface sank slightly around a rognon (rounded nunatak) at $3930 \mathrm{~m}$. A photograph taken by Marmillod of the eastern slopes of Cerro Portillo above $4000 \mathrm{~m}$. shows no change at all between $195^{\circ}$ and 1956 .

To summarize, then, the lower part of the Glaciar Universidad had a true glacier flood (in the sense of this term used by Tarr and Martin) around 1943, followed by a spectacular recession from 1946-50; during this period the upper regions showed almost no variation. This is in agreement with the perfect plasticity theory.

\section{Cause of the Glacier Floods}

As I have already reported elsewhere, ${ }^{1,} 7$ this is not the only glacier flood which has occurred in the central Andes. In 1927 the Glaciar Colina (the Chilean tongue of the Glaciar Nieves Negras, south of Volcán San José) advanced 4-5 km. In 1934 the Ventisquero del Nevado (south-east of Nevado del Plomo) advanced and dammed the Río Plomo. In 1935 the Glaciar del Río Museo (west of Mesón San Juan) advanced $5 \mathrm{~km}$. In 1947 the Glaciar Juncal Sur (south of Nevado Juncal) advanced $3 \mathrm{~km}$. and reached a cirque $600 \mathrm{~m}$. lower; in $195^{\circ}$ its surface was still very crevassed, but when I visited it in I953, there were only circular crevasses around a subglacial cave.

Helbling and Reichert, ${ }^{8}$ perhaps influenced by the observations of Tarr and Martin, ${ }^{4}$ attribute the formation of the Río Plomo dam to the action of an earthquake on a hanging glacier. I am not fully convinced of this, even though Reichert observed the disappearance of a hanging glacier between his visits in 1912 and 1935 ; in five years I have never seen such a fall of a hanging glacier, nor the remnants of one, the only exception being a scar left by the fall of the Glaciar Colgante del Nevado Juncal. This particular fall, which von Klebelsberg takes as an example of the fall of a hanging glacier, was only about a half as large as the fall of the Glacier du Tour. In central Chile, hanging glaciers are scarce because it only snows during the cold season and so snow cannot remain on the steep slopes. Falls of ice are almost unknown because glaciers in this region are cold and welded to the bedrock. Whatever the truth may be, the collapse of hanging glaciers can have had nothing to do with the sudden advances of Glaciar Juncal Sur or Glaciar Universidad. On both these glaciers there are only hanging glaciers above one of the branches, and if the sudden advance had been caused by their fall, this should have produced a twisted medial moraine below the junction of the branches a few years later. I should therefore have seen the end of such a lateral displacement if the "wave" had moved with the ice, or the whole lateral displacement somewhere between the front and the junction if the wave had moved faster than the ice, yet in fact both branches appeared to have advanced equally.

The years 1898 to 1905 (except for 1903 ) were very rainy years in Chile. The mean annual rainfall in Santiago was $56 \mathrm{~cm}$. for these 8 years, compared with $37 \mathrm{~cm}$. between 1849 and 1953. As the histogram of precipitation in Santiago shows a bimodal distribution, it is approximately true to say that one year in 5 is an exceptionally wet year with $66 \mathrm{~cm}$. of rain instead of $30 \mathrm{~cm}$., but between 1898 and 1905 there were 6 exceptionally wet years in 8 . These favourable years have activated an advance of the glacier fronts after an interval of 20 to 40 years.

The problem is to explain the suddenness of the advance. Among the reasons there are local factors: a cirque $600 \mathrm{~m}$. below the snout of the Glaciar Juncal Sur, and ice coming over 
a narrow gap into the Glaciar Universidad. I think these reasons are insufficient, and I have already proposed a thermal explanation in the case of Glaciar Juncal Sur (see ref. I, p. 232). After dry years, the area of glacier bed which is at the pressure melting point increases, due to the converse of the Robin effect; but this explanation is not applicable to the Glaciar Universidad, which is, as we shall see, a temperate glacier.

The total snowfall on the Glaciar Universidad is very different in the upper and lower parts, as precipitation can fall as rain on the lower part, thus it is possible that between 1898 and 1905 only the upper parts of the glacier increased, and that several smooth slopes around the eastern branch, now ice-free, became glacierized. Now, as a glacier flows more swiftly the thicker and broader it is, the upper part of this broad supplementary layer would flow faster than the lower part and would pile up against it, forming a great bulge or wave by the time it reached the front.

\section{Appearance of the Glacier Surface}

At the end of the $1955-56$ summer (a normal year as regards amount of precipitation), the firn line was at about $3200 \mathrm{~m}$. It was somewhat lower at the foot of the western slopes, and much higher on the exposed upper parts of these slopes. The smallest glaciers in this area in the neighbouring valleys never penetrate below $3500 \mathrm{~m}$., so it would seem that the firn line on Glaciar Universidad is rather lower than the equilibrium line of the smallest glaciers.* This was the first difference noticed from the glaciers further north, above Santiago; there, at the end of summer, the firn line on the large glaciers is some 200 to $500 \mathrm{~m}$. higher than the smallest glaciers because a great part of the winter snow has turned into ice.

The superficial appearance of Glaciar Universidad confirms that it is not of the subtropical type (Avsyuk's Continental type) as are the glaciers to the north and east. It is the first glacier going south of the alpine type (Avsyuk's Maritime type). The most striking fact is the absence of penitentes above $3800 \mathrm{~m}$.; neither the author in 1956 , nor Marmillod in I950 found any around Cerro Portillo. Ten kilometres to the south-south-east (lat. $34^{\circ} 50^{\prime} \mathrm{S}$.) on the eastern slopes of Volcán Tinguiririca, I found penitentes more than I $\mathrm{m}$. high above $3800 \mathrm{~m}$., which are perhaps the most southerly in Chile. Before reaching this place, the wet western wind will have dried while crossing a great, basaltic plateau at $3000 \mathrm{~m}$. On the Argentine side, penitentes are found further south. $\dagger$

On the Glaciar Universidad at $2600 \mathrm{~m}$., in the middle of the ablation zone, another transitional feature, often noticeable in the driest areas of the Alps, is to be found; this is a feature which Workman studied in the Karakoram and named pocket-penitents. ${ }^{10}$ These are elliptical holes, two inches to a foot deep $(5-30 \mathrm{~cm}$.), filled with water. Their major axis is east-west, and the bottom flat or covered with sand or mud. The northern side, which is in shadow, extends upwards as an east-west ridge about $20 \mathrm{~cm}$. above the surface (Fig. 6 , p. 269).

In the same area I observed little glacier mills, a feature which does not exist in subtropical glaciers, and which prove that, at least in the ablation zone, the ice is at the melting point inside the glacier.

Several dirt cones were also seen. One was formed by mud deposited in a meander of a superglacial stream, another at the extremity of a transverse moraine which will be discussed again later, came from sand which had filled a crevasse; yet others were formed from old glacier tables. These three mechanisms have already been described by Streiff-Becker,

* The term firn line is here used to mean the highest level reached by the snow line during the year; equilibrium line is the line where the net ablation, allowing for refreezing, equals the accumulation, it is thus the line where ice moves parallel to the surface and where the flow is a maximum.

$\dagger$ However, the features observed by Neumeyer 9 on Volcán Lanín were probably skavler rather than penitentes. The most southerly glacier with penitentes is probably one on Volcán Domuyo (lat. $36^{\circ} 36^{\prime} \mathrm{S}$., $4660 \mathrm{~m}$. high), but I can give no reference on this point. 
Swithinbank and myself. Dirt cones are a sign of abundant melt water flowing on the glacier and cleaning its surface of all debris which is not elevated above the general level.

I also noticed in the ablation zone deep, elliptic holes filled with water, containing large horizontal submerged ice crystals. The origin of these crystals has been a matter of discussion, ${ }^{11},{ }^{12}$ but I am convinced that they are crystals formed on the surface of the water when it was at a lower level; it has been known since the time of Agassiz ${ }^{\mathrm{I} 3}$ that glacier ice is not completely impervious, and so the water table can sink after cool, dry weather.

In short, the superglacial features on Glaciar Universidad are the same as those in the driest regions of the French Alps at similar altitudes (for instance on the Glacier de SaintSorlin). We can therefore say that the climate is similar.

\section{Blue Bands and Wave Ogives}

The ablation area of the western branch of Glaciar Universidad, which was the only one visited, is foliated throughout with thin layers of bubble-free ice, spoon-shaped and outcropping forwards. Without prejudging the origin of these blue bands, I can say that, near the foot of the ice fall they emerge at $45^{\circ}$, i.e. along planes of maximum shear, but I never saw shearing along a blue band in the sense that the ice up-glacier was higher; on the contrary, at the bend, where the flow becomes extending, shears of 5 to $15 \mathrm{~cm}$. have occurred along these blue bands, the part up-glacier being lower. This uncommon kind of shear may be due to the presence of crevasses.

With the differential movement of the ice, the blue bands bend down more and more until they practically coincide with the lines of flow; therefore near the snout the blue layers make an angle of $25^{\circ}$ with the surface, and at the snout itself, an angle of $10^{\circ}$ to $15^{\circ}$.

I do not know whether we should use the term "blue bands" for the outcrops of these thin, bubble-free layers, or for the layers themselves. The system of outcrops was called "echte Ogiven" by von Klebelsberg, and incidentally "fine ogives" by Glen. Rather than argue about nomenclature, it is more important to note that this bubble-free ice is less weathered by the sun than the surrounding white ice, and thus the dirt carried by melt water between the weathered grains is collected by the "blue bands", which are no longer blue but covered with mud. These dark lines of mud are a purely superficial feature, as can be seen in Fig. 7 (p. 269).

The wave ogives are very neat near the ice fall, although most of them are subdivided into several ogives of shorter wavelength which join together after the bend. The distance between two ogives (or between two groups of shorter ones) diminishes progressively down glacier. The wave ogives and the fine, blue ogives have the same convex curve; probably the curve which any line crossing the glacier at the foot of the ice fall would assume.

The waves have white northern slopes and dark southern slopes, an appearance that is purely superficial (note the walls of crevasses in Fig. 8, p. 269). On the northern slopes, which are more exposed to the sun, and where fewer blue bands reach the surface because their mutual angle is more acute, dirt is less abundant, and lies concentrated and hidden in melt holes. On the southern slopes, less exposed to the sun, and with more blue bands reaching the surface, the dirt remains on the surface, at first lining the blue bands and then forming a continuous dirt cover. This cover itself prevents the ice beneath from uneven weathering and melting. I am almost convinced that the same explanation accounts for the famous Forbes' Bands of the Mer de Glace, with north and south of course interchanged; the dark bands are only a superficial and secondary feature which appears on the northern slopes of the wave ogives and then reinforces itself.

At various places near the bend of the glacier almost vertical ice veins were noticed. They are inclined at about $20^{\circ}$ to the vertical in the forward direction, and so cut the blue bands at about $25^{\circ}$. The forward part is about $10 \mathrm{~cm}$. below the upper part. I think that they are old, closed crevasses which have since acted as shear cracks. The ice of these veins is pure 
and bubble-free, with the exception of that in two very close veins (about 5 to $15 \mathrm{~cm}$. apart), which have dirty, laminated ice.

Moraines of Rounded Material

As mentioned above, the plain below the glacier is covered with sand and rounded blocks of granodiorite coming from valleys further to the east. The same rounded material forms two superglacial deposits which contrast strongly with the very angular material coming from the upper slopes.

(a) Transverse moraine. At about $200 \mathrm{~m}$. from the front there is a very curious transverse ice-cored moraine $600 \mathrm{~m}$. long, with a broad break in the middle (see Fig. 5). This moraine is formed of sand and pebbles emerging from three cracks which are almost in line. On either side of the deposit, several further parallel cracks are visible, but without any deposit inside. The outcrop of the cracks is parallel to the outcrop of the blue bands, but their angles of dip are quite different; about $60^{\circ}$ compared with $25^{\circ}$ (Fig. 9, p. 269). At the western extremity the last crack becomes 20 to $50 \mathrm{~cm}$. broad and vertical, and is filled with unstratified sand. It is obvious that these cracks are old closed crevasses, perhaps old concentric crevasses around a collapsed cave such as exist to-day somewhat to the west. The interruption in the middle is proof that these cracks do not extend to the bottom of the glacier.

Thus, although this moraine is very similar to one described by Mr. Ward in Baffin Island, ${ }^{14}$ we cannot here follow him in his conclusions. On the Glaciar Universidad at least, this transverse, rounded moraine comes from an infilled crevasse and a superglacial stream, and has not been picked up from the bottom by the glacier, as Ward supposed. Although not stratified it qualifies more for the name of "esker" than that of "moraine".

(b) Covered lobe. Very near this deposit the front forms a lobe of about $100 \times 100 \mathrm{~m}$. , all covered with such rounded pebbles (see the right of Fig. 5). In the cliff around the lobe on the eastern side, close to the end of the deposit, one can see strata of frozen earth and rounded pebbles embedded in the ice. The strata are here parallel to the blue bands, which are inclined at only $15^{\circ}$ to the horizontal. In the upper part of the cliff, strong shearing has occurred along the strata (Fig. Io, p. 269). A similar case of frontal and almost horizontal shear has been reported by Cotton on the Franz Josef Glacier. ${ }^{15}$

In this case as well it looks at first sight as though the sand and pebbles have been picked up from the bed by shear planes, and the possibility of this mechanism cannot be completely rejected. Nevertheless, the frozen earth is not laminated, and does not have the fluidal structure which appears after a few hundred metres of shear. The ice, which is very old, appears to have been motionless for a long time, particularly at the end of the lobe. The crystallites are the size of hens' eggs and almost free from bubbles; between the crystallites there are great elongated bubbles filled with air at atmospheric pressure. The direction of the bubbles is uniformly vertical, although the optic axes are variable in direction. Some crystals show definite slip planes, along which cleavage is possible, and which are parallel to the earth strata. I have observed such elongated and vertical intercrystalline bubbles of air many times in dead ice, near the bed or in a glacial cave. I attribute them to recrystallization of the ice in a temperature gradient. Thus I question whether this lobe may not be a remnant of old masses of dead ice left by the glacier after previous advances, which has recently been squeezed and sheared.

\section{Acknowledgements}

I should like to express my thanks to the Rector of the University of Chile, Don Juan Gomez Millas, who made this reconnaissance possible; also to the Estado Mayor General del Ejercito and the Instituto Geográfico Militar of Chile for allowing me to have some aerial photographs.

$M S$. received 3 December 1957 


\section{REFERENCES}

1. Lliboutry, L. Nieves y Glaciares de Chile, Fundamentos de Glaciología. Santiago, Ediciones Universidad de Chile, I 956.47 I p.

2, 3. Haefeli, R. Some observations on glacier flow. Journal of Glaciology, Vol. 1, No. 9, 1951, p. $49^{6-98}$ and correspondence ibid., No. 10, 1951, p. 580-82.

4. Tarr, R., and Martin, L. Alaskan Glacier Studies. Washington, National Geographic Society, 1914. 498 p.

5. Morandini, G. Osservazioni sulla struttura e su alcune forme di crepacci del Ghaicciaio del Mandron (Adamello). Bollettino del Comitato Glaciologico Italiano, Ser. 2, No. 1, 1950, p. 19-29.

6. Boer, G. de. Ice margin features, Leirbreen, Norway. Fournal of Glaciology, Vol. I, No. 6, 1949, p. 332-36.

7. Lliboutry, L. Le Massif du Nevado Juncal (Andes de Santiago), ses pénitents et ses glaciers. Revue de Géographie Alpine, Vol. 42, No. 3, r954, p. 465-95.

8. Helbling, R. The origin of the Río Plomo ice-dam. Geographical fournal, Vol. 85, No. I, 1935, p. 41-49.

9. Neumeyer, J. J. Nieve penitente en el Lanín. Anuario del Club Andino Bariloche, No. 19, 1951, p. 123.

10. Workman, W. H. Nieve penitente and allied formations in Himalaya. Zeitschrift für Gletscherkunde, Vol. 8, I914, p. 290-330.

I I. Schneider, A. Submerged ice crystals in glaciers. Fournal of Glaciology, Vol. I, No. 4, 1948, p. I77 and I90-91.

12. Putnam, W. L. Submerged ice crystals in glaciers. Fournal of Glaciology, Vol. I, No. 8, 1950, p. 456.

13. Agassiz, L. Nouvelles Etudes et Experiences sur les Glaciers Actuels. Paris, Victor Masson, 1847. 598 p.

14. Ward, W. H. The physics of deglaciation in central Baffin Island. Journal of Glaciology, Vol. 2, No. i i, I952, p. 9-22.

15. Cotton, C. A. Climatic Accidents in Landscape-Making. Christchurch, Whitcombe \& Tombs, r947. Plate XVI, Fig. 2. 


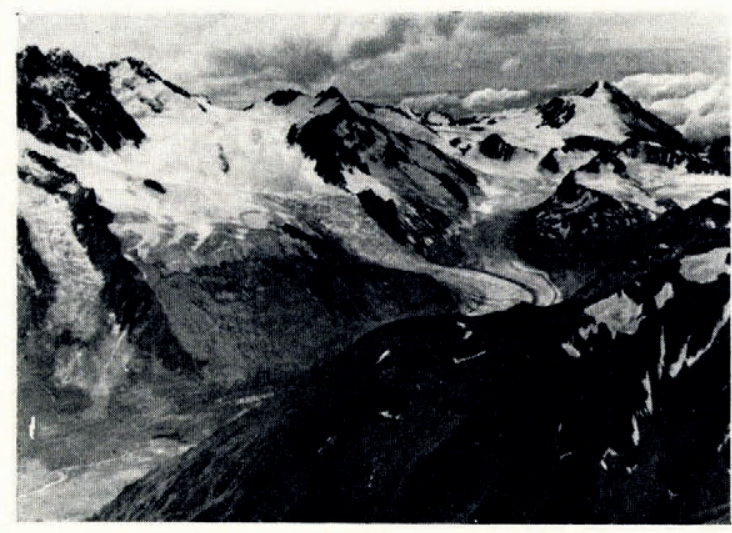

Fig. 3. Glaciar Universidad seen from the south. Right, Volcain Palomo (485o m.) ; left, Cerro Portillo (4986 m.

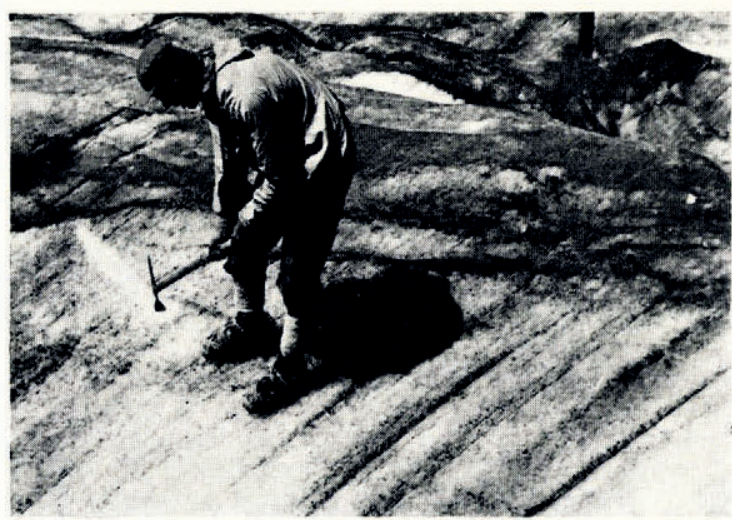

Fig. 7. Superficial mud lining blue bands, and then forming a continuous cover

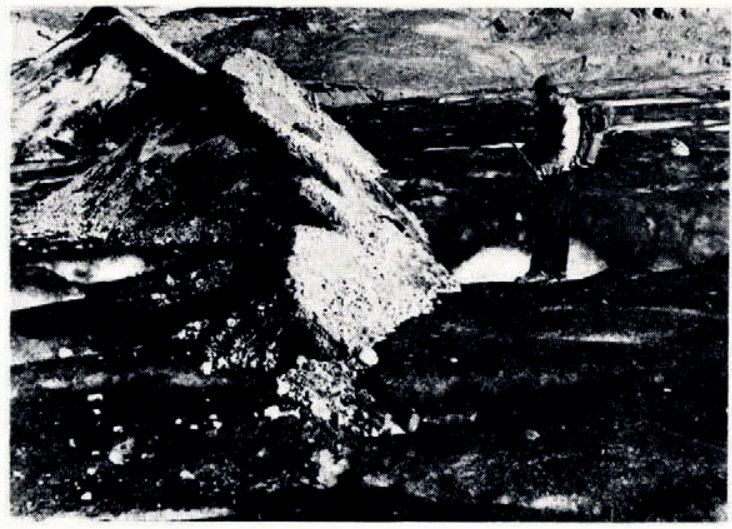

Fig. 9. Rounded material filling a closed crevase. Note another closed crevase in the background

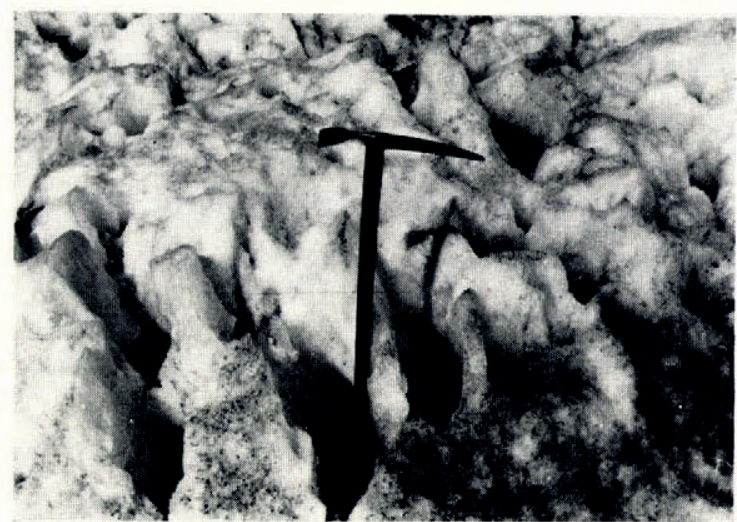

Fig. 6. "Pocket-penitents" on Glaciar Universidad at $2500 \mathrm{~m}$.

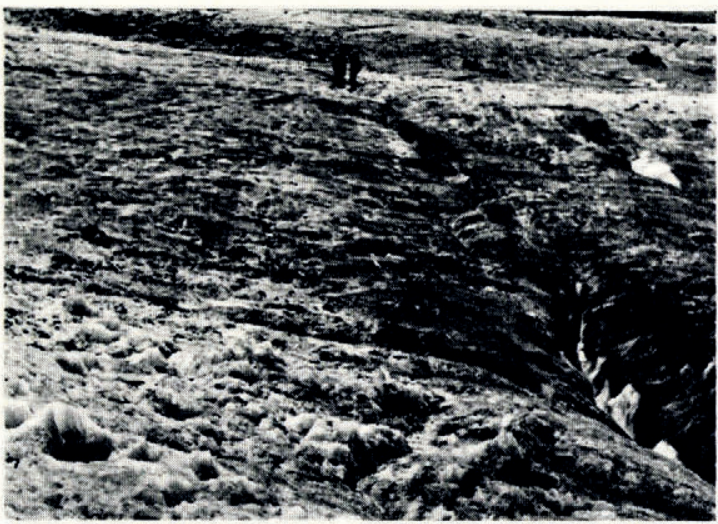

Fig. 8. Wave ogives on Glaciar Universidad. Figures in distance give scale

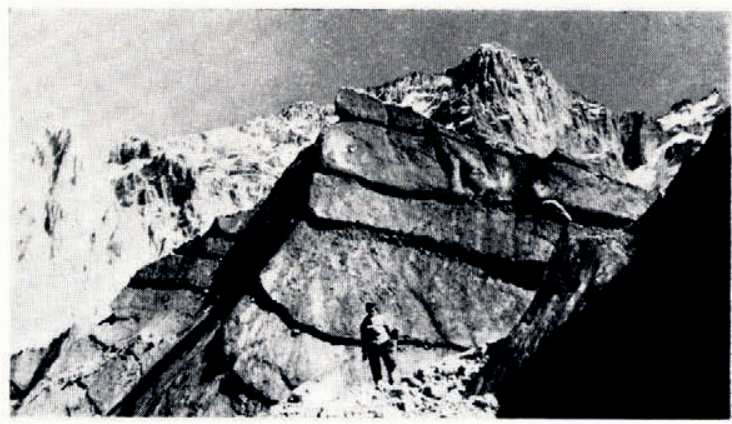

Fig. IO. Shear of the frontal cliff along beds of earth 


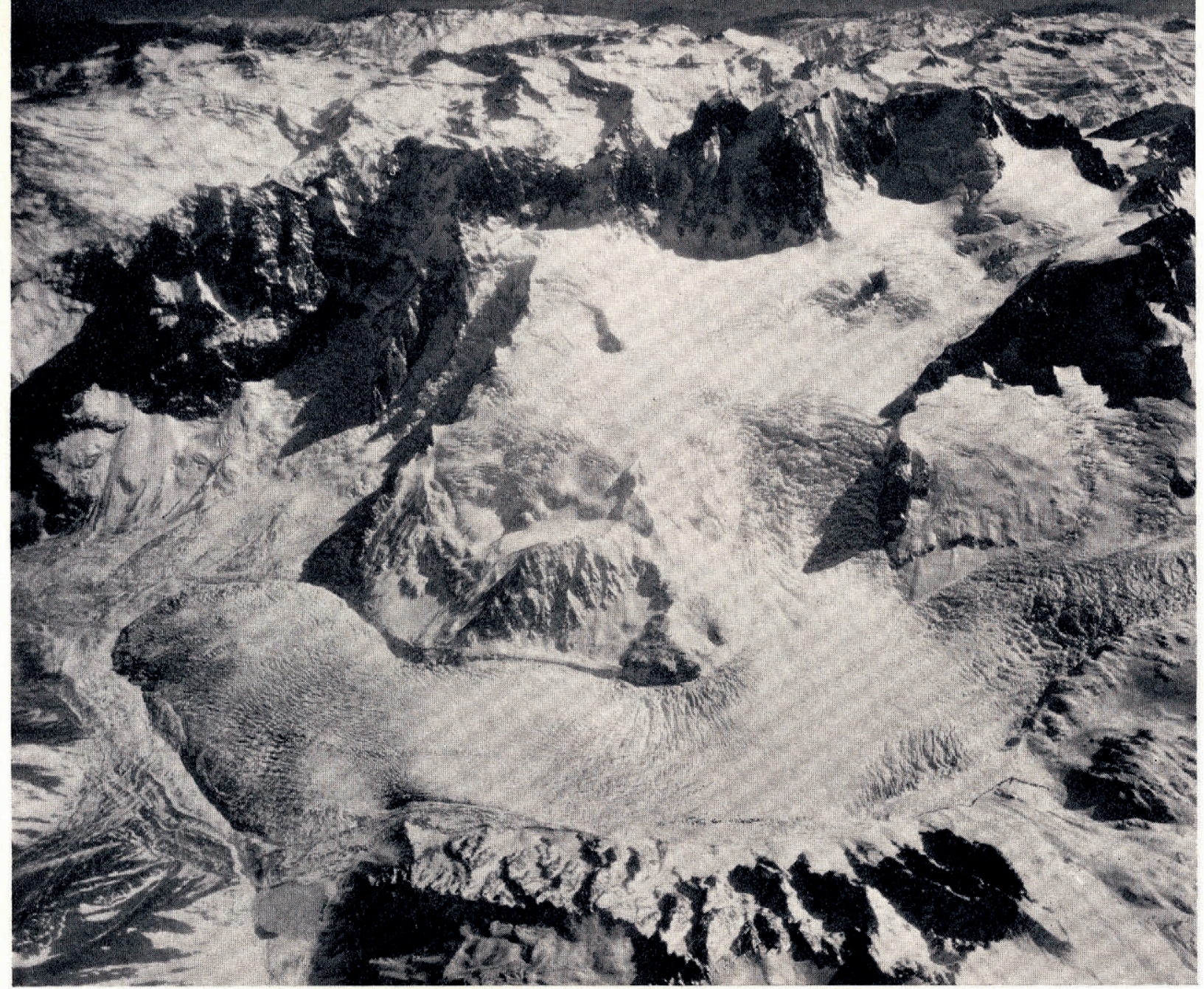

Fig. 2. Aerial view of Glaciar Universidad during the winter of 1945, just after a glacial flood. Wave ogives on both branches are hardly noticeable beneath the snow

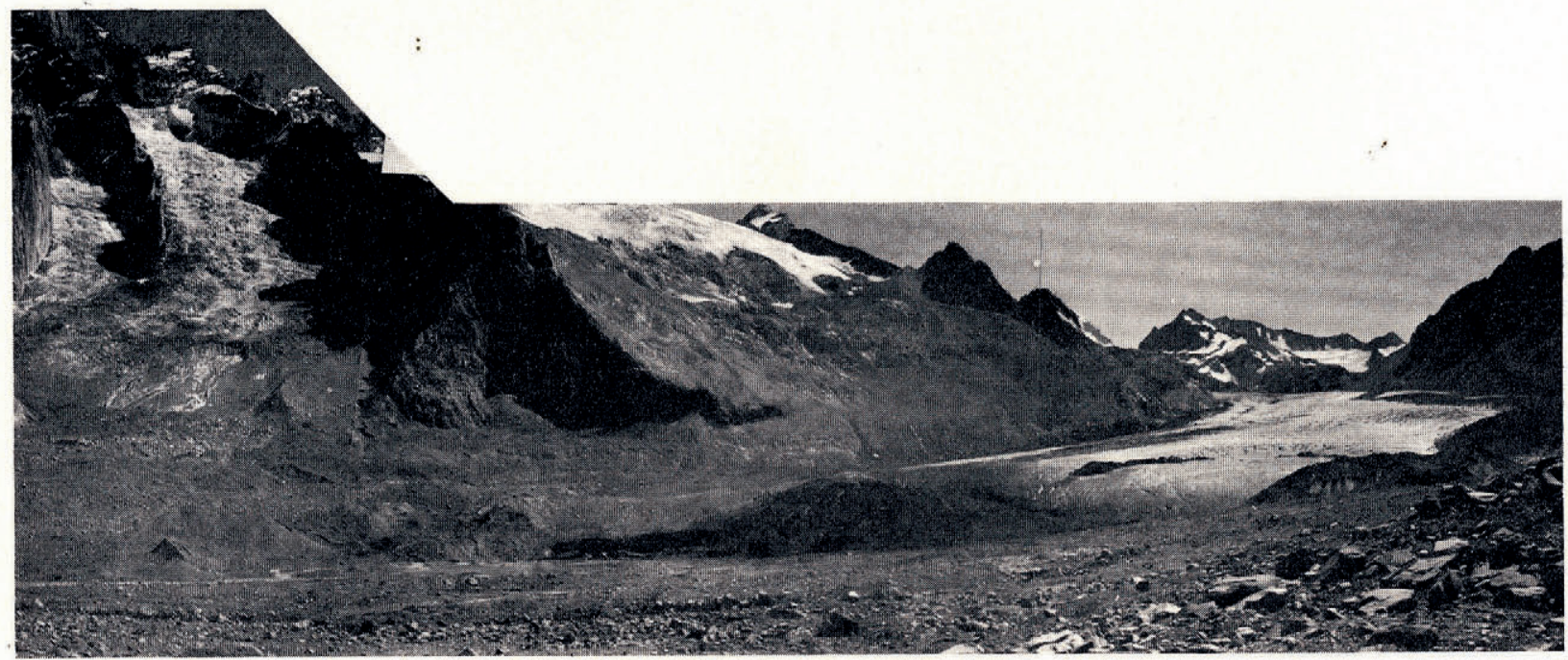

Fig. 5. Front of Glaciar Universidad in 1956. Note wave ogives, bend of medial moraine, transverse settled deposit, prominent lobes on right (smooth material) and middle (angular material), cones of dead ice on left 